\title{
UNDANG-UNDANG ISLAM DALAM MASYARAKAT MELAYU: ANALISIS TERHADAP BENTUK PEMIKIRAN DAN PANDANGAN R.O. WINSTEDT
}

\section{Islamic Law in the Malay Society: An Evaluation of R.O. Winstedt's Thoughts and Methodological Approach}

\author{
Mohd Farhan Abd Rahman* \\ Rahimin Affandi Abd Rahim **
}

\begin{abstract}
This article will focus on R.O. Winstedt's view concerning Islamic law in the Malay society, which emphasized more on the negative side rather than the positive side. In order to achieve such an objective, special attention is be given to the methodological approach used by Winstedt in the Islamic law. This article is divided into four sections. First, the introduction of the study; second, an evaluation of Winstedt's methodological approach and thought followed by, third, an analysis of Winstedt's point of view concerning Islamic law in the Malay Peninsula and finally the fourth, the conclusion and summary.
\end{abstract}

Keyword: R.O. Winstedt, Logico Positivesme, Alam Melayu, Sejarah Melayu, Charles Darwin

* Pensyarah, Pusat Pemikiran dan Kefahaman Islam (CITU), UiTM Kampus Alor Gajah, Melaka, farhan84_arau@yahoo.com.

** Prof. Madya, Jabatan Fiqh \& Usul, Akademi Pengajian Islam, Universiti Malaya, Kuala Lumpur, faqir_ila_rabbih@um.edu.my. 


\section{PENGENALAN}

R.O. Winstedt merupakan tokoh utama yang berpegang dengan fahaman logico-positivism, yang mana beliau dikatakan menggunakan pelbagai kaedah saintifik dalam mengambarkan perihal masyarakat Melayu secara terperinci seperti pemalas, suka berserah kepada takdir, suka berhutang dan sebagainya. Malah, pemikiran beliau lebih berbentuk skeptikal dalam menilai undang-undang Islam di Alam Melayu dengan didasari karya dan metode orientalis klasik dalam memberi penjelasan berkenaan kelemahan hukum Islam. Oleh itu, kajian ini akan menilai sejauhmana kebenaran yang dilontarkan oleh Winstedt selama ini terhadap Islam. Justeru, bagi melengkapkan kajian ini, penulis menggunakan kaedah tekstologi, perbandingan dan content analysis dalam menolak pandangan Winstedt terhadap undangundang Islam. Penulis juga menggunakan prinsip pertengahan bagi menghasilkan sesuatu kajian yang bersifat adil dan tidak berat sebelah.

\section{ELEMEN KHUSUS DALAM PEMIKIRAN YANG DIDOKONG OLEH WINSTEDT}

Hasil dari perbandingan dan penelitian penulis berkenaan persamaan metodologi pemikiran tokoh orientalis terdahulu seperti Snouck Hurgronje, Ignaz Goldziher dan Joseph Schacht dengan Winstedt, penulis mendapati pendekatan kesemua tokoh tersebut adalah sama, memandangkan ketiga-tiga tokoh tersebut merupakan pencetus kepada ideologi Winstedt dalam menilai sesuatu masyarakat berdasarkan pegangan mereka terhadap sistem keagamaan. Hasilnya, penulis mengenal pasti empat pendekatan khusus dalam pemikiran yang didokong oleh Winstedt, iaitu:

Pertama, pendekatan sarjana orientalis menggunakan falsafah fungsionalisme sebagai salah satu alat penjajahan di Tanah Melayu. ${ }^{1}$ Ini kerana penjajah Barat khususnya British sedar bahawa agama Islam adalah suatu aspek yang penting dalam kebudayaan masyarakat Melayu dan sebarang penghinaan terhadap agama

Anwar Din, Asas Kebudayaan dan Kesenian Melayu (Bangi: Penerbit Universiti Kebangsaan Malaysia, 2007), 37-38. 
tersebut akan menyebabkan penentangan masyarakat Melayu terhadap mereka. Dengan kesedaran itu, walaupun anti Islam penjajah British tidak pernah melakukan tindakan provokatif terhadap agama Islam. Sebaliknya secara licik penjajah British merendahkan taraf agama Islam dengan mengadakan Perjanjian Pangkor 1874. Kesannya Islam diasingkan daripada politik. Raja Melayu dilantik sebagai ketua agama tetapi bidang perundangan Islam dihadkan kepada hal ehwal perkahwinan dan perkaraperkara furu' sahaja. ${ }^{2}$

Kedua, falsafah humanisme ${ }^{3}$ ialah satu pendekatan yang melibatkan kebahagiaan dan kebajikan manusia sebagai subjek yang palingutama. Ianyamenumpukan semuaurusan pembangunan kehidupan dunia ini tanpa sebarang pertimbangan akhirat sematamata untuk kepuasan diri dan nafsu manusia. Falsafah ini kemudiannya telah melahirkan sejumlah besar paradigma disiplin keilmuan bagi tujuan pengurusan dan pembangunan tamadun materialistik.

Ketiga, pendekatan rasionalisme merupakan satu fahaman yang mengagungkan keupayaan akal dalam mengatasi segala persoalan hidup berdasarkan kaedah logik akal, malah wahyu tidak dianggap berwibawa dalam memandu pemikiran manusia. ${ }^{4}$ Pendekatan tersebut turut ditunjangi prinsip pragmatisme yang mana mementingkan kehendak majoriti masyarakat walaupun salah dan memberi impak yang buruk kepada akidah dan akhlak masyarakat seperti trend yang mengakui amalan seks bebas dan homoseksual. Memandangkan orientalis yang berpandukan kepada fahaman sekularisme iaitu fahaman yang memisahkan hal-hal agama dengan segala urusan dunia, sudah semestinya golongan ini menerima pendekatan rasionalisme tersebut.

Keempat, pendekatan diffusionisme yang menganggap kemajuan masyarakat Melayu bukan kerana sifat asal diri mereka

2 Auni Abdullah, Tradisi Pemerintahan Islam \& Kolonialisme Dalam Sejarah Alam Melayu (Kuala Lumpur: Darul Fikir Sdn. Bhd, 2005), 1-35.

3 Mohd Kamal Hassan, Toward Actualizing Islamic Ethical and Educational Principles in Malaysia (Kuala Lumpur: ABIM, 1996), 39.

4 Sila lihat Auni, Tradisi Pemerintahan Islam, 102. 
yang baik dan proaktif terhadap sesuatu kemajuan, tetapi kerana faktor pengaruh budaya asing (difusi budaya) yang secara langsung telah ditiru secara selektif oleh masyarakat Melayu. ${ }^{5}$ Sikap ini secara terang-terangan telah menafikan kepandaian masyarakat tempatan (local genius) di dalam membina sesuatu tamadun tempatan yang tinggi. ${ }^{6}$ Antara budaya asing yang kononnya telah mencirikan kebudayaan Melayu adalah Hindu-Budhha, Arab, India dan Parsi. Bahkan, apabila mengkaji pengaruh Islam terhadap jati diri orang Melayu, mereka telah menggambarkannya secara skeptik dengan mengatakan bahawa masyarakat Melayu sebenarnya tidak mempunyai pegangan keislaman yang cukup kuat, hanya di lapisan kulit luar semata-mata, sedangkan isi dalamnya masih lagi berteraskan budaya pra Islam iaitu animisme dan Hindu. ${ }^{7}$

\section{ANALISIS PANDANGAN WINSTEDT TERHADAP UNDANG-UNDANG ISLAM DI TANAH MELAYU}

Hubung kait di antara kedatangan pihak penjajah dengan perubahan-peruhahan yang berlaku ini sebenarnya disumbangkan oleh faktor intrinsik dalam minda penjajah itu sendiri. Pemikiran Winstedt didasari oleh teori darwinisme iaitu kepercayaan yang ditanam dalam setiap idealogi orang Barat, yang mana mereka mempunyai tanggungjawab yang besar untuk mentamadunkan bangsa lain khususnya masyarakat di kawasan timur, atau lebih tepat lagi yang masih menjadikan agama Islam sebagai sistem kepercayaan dalam kehidupan mereka. Apa yang dilontarkan oleh Winstedt ini merupakan sebahagian daripada misi penjelajahan bangsa Barat di Nusantara amnya, dan Tanah Melayu khususnya.

Teori logico-positivism yang digagaskan oleh Charles Darwin ini jelas cuba menegakkan ideologi kecerdikan manusia yang

Zainal Kling, "Antropologi Tafsiran: Sumbangan Kebudayaan Melayu Kepada Teori”, dalam Syarahan Perdana Untuk Pengukuhan Profesor (Kuala Lumpur, 1994), 8-10.

6 Bryan S. Turner, "Gustave E. Von Grunebaum and the Mimesis of Islam”, dalam Orientalism, Islam and Islamist, ed. Asaf Hussein, (Vermont: Amana Books, 1984), 193-201.

7 K.P. Landon, Southeast Asia: Crossroad of Religions (Chicago: University of Chicago, 1949), 202-203. 
unggul, yang hanya mementingkan bukti-bukti saintifik, yang memandang tinggi tanggapan bahawa hanya bangsa Eropah sahaja yang memiliki kecerdikan otak berbanding bangsa Timur. Lantaran itulah Winstedt gagal memahami kebudayaan dan pemikiran masyarakat Melayu yang sebenar kerana beliau sendiri enggan mengakui nilai-nilai ketinggian pemikiran bangsa yang beliau kaji. Atas dasar inilah, timbulnya dakwaan yang menafikan kepandaian masyarakat tempatan (local genius) di dalam membina sesuatu tamadun tempatan yang tinggi. ${ }^{8}$

Bermula dari teori itulah Winstedt dengan pandangan skeptikalnya berkenaan Islam dan masyarakat Melayu telah memberikan penilaiannya yang tersendiri, iaitu:

1. Beliau menyatakan bahawa Islam di Tanah Melayu merupakan persis dari agama Hindu dan dipengaruhi dengan kepercayaan Hinduisme. Ini berdasarkan kajian beliau bahawa Islam di rantau ini dibawa dari India berdasarkan pewarnaan latar belakang India Selatan yang kuat di Pasai.

2. Islam adalah agama yang terhasil dari budaya Timur Tengah yang memerlukan suatu kerangka yang agak keras dan unik bersesuaian dengan latar belakang iklim dan masyarakat Timur Tengah, yang sudah pasti tidak sesuai untuk bangsa yang bukan dari negara Arab, seperti Tanah Melayu. ${ }^{9}$

3. Paparan tentang Islam diakui sendiri oleh Winstedt sebagai sangat kabur. Beliau hanya memberikan paparan yang negatif tentang Islam berasaskan kepada sumber fantasi, cerita dongeng ${ }^{10}$ dan mitos yang memburukkan Islam tanpa sebarang bukti yang kukuh.

4. Menafikan sumbangan bernilai yang diberikan oleh ajaran Islam ke arah mewujudkan tamadun kemanusiaan yang berharga. Hal ini secara jelasnya tidak terhad kepada implikasi dan proses Islamisasi di kawasan Timur Tengah,

8 Bryan S. Turner, "Gustave E. Von Grunebaum and the Mimesis of Islam”, dalam Orientalism, Islam and Islamist, ed. Asaf Hussein, 193-202

9 W.M. Watt, Economic and Social Aspects of the Origin of Islam, dalam The Islamic Quarterly 1, pt. 1 (1954): 97.

10 R.O. Winstedt, A History of Classical Malay Literature (Kuala Lumpur: Oxford University Press, 1969), 10-25. 
bahkan turut dilanjutkan penafiannya terhadap kawasan luar Timur Tengah termasuklah dunia Alam Melayu, yang dilihat telah terpengaruh secara berkesan dengan ajaran Islam.

5. Islam tidak boleh dianggap sebagai way of life (al-Dinn), tetapi hanya sebagai hasil sejarah silam yang tidak relevan lagi untuk zaman sekarang. Syariah yang merupakan senjata orang Islam adalah tidak bersifat maksum (infallible), universal dan fleksibel mengikut kesesuaian untuk sepanjang zaman, dan hanya sesuai dijalankan pada zaman dahulu bagi masyarakat Timur Tengah sahaja. Oleh sebab itu, seandainya umat Islam inginkan kemajuan yang sejati, secara jelas mereka perlu menolak Syariah disifatkan ketinggalan zaman dan mengantikannya dengan undangundang Barat yang kononnya lebih bersifat semasa. Malah Winstedt menganggap orang Islam di Timur Tengah sebagai bangsa Barbar yang ganas dan patut dibenci kerana mereka dahagakan darah penganut Kristian.

Bagimengkritikpandangan Winstedtberkenaanundang-undang Islam di Tanah Melayu, penulis mendatangkan dua pendekatan yang bersifat wasatiyyah (pertengahan) iaitu pendekatan mitologi dan tekstologi. Kedua-dua pendekatan ini amat sesuai bagi menjawab segala tohmahan yang digambarkan oleh Winstedt berkaitan undang-undang Islam. Pendekatan kajian yang bersifat wasatiyyah ini menerapkan paradigma pertengahan di antara dua sikap ekstrem, di antara sikap yang terlalu positif dan sikap yang terlalu negatif. Ianya bertujuan untuk menghasilkan sesuatu kajian yang bersifat adil dan tidak berat sebelah.

Dalam mengkritik tanggapan Winstedt berkenaan teori Islam yang dianuti oleh orang Islam di Tanah Melayu bukanlah Islam yang asli dari Timur Tengah, tetapi merupakan "campuran Islam di India" persis dari agama Hindu dan dipengaruhi dengan kepercayaan Hinduisme, ${ }^{11}$ penulis menjadikan pendekatan mitologi sebagai panduan utama bagi menjawab persoalan tersebut. Tidak

11 R.O. Winstedt, "The Early Muhammadan Missionaries", dalam JSBRAS (1920), 4-7. 
dapat dinafikan bahawa teks-teks sejarah Melayu Islam pada kurun ke-14 hingga ke-19 mempunyai unsur-unsur mitologi. ${ }^{12}$

Salah satu mitos penting dari segi sejarah perkembangan masyarakat Melayu ini adalah mitos tentang asal usul raja-raja Melayu. Mitos mengenai asal usul raja-raja Melayu adalah suatu alat yang sangat penting bagi mempengaruhi pandangan umum untuk menjadikan "wajah positif" raja dan untuk mempromosikan "keadilan" dan keabsahan kerajaannya. Dalam karya sejarah Melayu yang mewakili historiografi Islam terawal, iaitu dalam Hikayat Raja Pasai dan Sejarah Melayu, didapati beberapa unsur mitologi tradisional. Dalam Hikayat Raja Pasai, bahagian pertama daripada mitos yang tradisional itu sudah hilang, iaitu hilangnya maklumat yang berkaitan dengan teogoni iaitu ceritacerita mengenai asal usul dewa dewi dan perkahwinannya, transformasinya, perkelahian di antara mereka dan lain-lain. Sebenarnya dalam Islam, langsung tidak ada unsur-unsur teogoni. Maklumat tersebut banyak terdapat dalam mitos India, Greek atau Shumer (Sumer).

Menurut pendapat T. Arnold, Hamka, S.M.H. Naynar dan lainlain, ${ }^{13}$ pada kurun ke-7 hingga ke-8 orang Melayu sudah mengenali Nabi Muhammad SAW dan orang Muslim. Ada juga beberapa

12 Mitologi adalah suatu bahagian penting dalam kehidupan intelektual, yang mana ianya mencerminkan pandangan umum iaitu pandangan orang biasa, cara pemikiran tradisional yang biasanya tidak boleh diubah secara segera atau sengaja. Penganalisaan tersebut memberikan kesempatan untuk membina semula sejarah yang tulen. Lihat Tatiana A. Denisova, Refleksi Historiografi Alam Melayu (Kuala Lumpur: Penerbit Universiti Malaya, 2011), 17-18.

13 Tentang sejarah masuknya Islam ke Asia Tenggara lihat T. Arnold, Preaching of Islam, (London, 1913), Haji Abdul Malik Karim Amarullah, "Masuk dan Berkembangnya Agama Islam di Daerah pesisir Sumatera Utara", dalam Sejarah Masuknya Islam ke Indonesia: Risalah Seminar (Medan, 1963), 72-95; S. Muhammad Hussayn Nainar, Islam di India dan hubungan-hubungannya dengan Indonesia (Medan: Information Service of India, 1956) \& Tatiana A. Denisova, "Islam di Dalam Alam Melayu Abad ke-VII sehingga keXIII”, dalam Sejarah Perkembangan Tamadun Islami, jil. 1, (2001). 
bahan daripada sumber sejarah $\mathrm{Arab}^{14}$ mahupun China ${ }^{15}$ yang memaklumkan bahawa pada abad pertama Hijrah orang Muslim pernah melawat ke Alam Melayu. Pendeta dan pengembara China I Tsing, yang mengunjungi Sriwijaya (San'fotsi) pada tahun 671 telah melaporkan bahawa beliau pernah bertemu saudagar Muslim dari negara Arab dan Parsi di Barus. H.M. Zainuddin dalam bukunya Tarich Atjeh dan Nusantara, ${ }^{16}$ menceritakan mengenai seorang Muslim bernama Zahid yang bersama-sama dengan kelengkapan Parsi menuju ke China Selatan dan singgah di Acheh, Kedah, Jawa, Brunei dan lain-lain.

Bahan yang penting untuk dijadikan bukti mengenai sejarah kemasukan Islam ialah dari teks Hikayat Raja Pasai, yang menceritakan mengenai Merah Silu dan semua rakyat Samudera Pasai. ${ }^{17}$ Dalam teks tersebut terdapat:

24(13) Sekali persetua pada zaman Nabi Muhammad Rasulullah SAW tatkala lagi hayat hadirat yang maha mulia itu, maka bersabda ia kepada sahabat baginda di Makkah, demikian sabda baginda "bahawa ada sepeninggalku wafat itu, ada sebuah negeri di bawah angin, Samudera namanya; apabila ada didengar khabar negeri itu maka kamu suruh sebuah kapal membawa perkakas alat kerajaan dan kamu bawa ia orang dalam negeri itu masuk Islam serta mengucap dua kalimah syahadat. Syahdan lagi akan dijadikan Allah SWT dalam negeri itu terbanyak daripada segala wali Allah jadi dalam negeri itu. Adapun pertama ada seorang fakir di negeri Mengiri namanya ia itulah kamu bawa serta kamu ke negeri Samudera itu.

14 Lihat Ibn Khurdadhbeh, Kitāb al-Masālik wa al-Mamālik, ed. M.J. De Goeje, (Leiden, 1889), t. h.

15 J. Takakusu, I Tsing: A Record of the Buddhist Religion as Practiced in India and the Malay Archipelago (A.D. 671-695) (New Delhi: Oxford University Press, 1966), 80-83.

16 H.M. Zainuddin, Tarich Atjeh dan Nusantara (Medan: Pustaka Iskandar Muda, 1961), 272-277.

17 Tatiana, Refleksi Historiografi Alam Melayu, 24-25. 
24-27 (14-15) Hatta maka beberapa lamanya kemudian daripada hadirat Nabi SAW wafat, maka terdengarlah khabarnya kepada syarif yang di Makkah, ada suatu negeri di bawah angin bernama Samudera, maka oleh khalifah Syarif, maka ia menyuruh sebuah kapal akan membawa segala perkakas alat kerajaan ke negeri Samudera. Setelah sudah kapal itu lengkap maka disuruh Syarif Syeikh Ismail itu singgah ke negeri Mengiri. Setelah sudah maka Syeikh Ismail pun naik ia ke kapal maka lalu ia berlayar.

.... Adapun raja dalam negeri itu Sultan Muhammad namanya.

.... Adapun Sultan Muhammad itu daripada anak cucu hadrat Abu Bakar bin Siddik radiallahu 'anhu. Maka sultan menyuruh hantarkan segala makanmakanan dan segala nikmat akan Syeikh Ismail.

.... Maka sultan pun merajakan seorang anaknya yang tua di negeri Mengiri itu akan gantinya kerajaan. Maka baginda dua beranak dengan anaknya yang muda memakai pakaian fakir meninggalkan kerajaannya, turun dari istana lalu naik kapal itu. Katanya pada orang kapal itu, "kamu bawa hamba ke negeri Samudera".

29(16) Hatta berapa lamanya maka kapal Syeikh Ismail pun sampai ke Teluk Terli, maka kapal itu pun berlabuh. Maka fakir itu pun naik ke darat. Maka ia bertemu dengan seorang orang menjala ikan. Maka kata fakir itu "Apa nama negeri itu?" Maka sahutnya orang itu: "Ada pun nama negeri ini Samudera".

31(16) Maka disuruh oleh Syeikh Ismail himpunkan segala hulubalang dan segala rakyat besar kecil dan tua muda laki-laki perempuan. ... Maka diajari oleh Syeikh Ismail mengucap syahadat akan mereka itu sekalian. Maka segala mereka itu relalah ia mengucap dua kalimah syahadat dengan tulus ikhlas 
yakin hatinya. Sebab itulah dinamai Samudera itu Negeri Darussalam kerana tiada sekaliannya orang itu dengan digagahi dan dengan tiada dimusakatkannya dan tiada dengan diperlekehkannya pada mengerjakan kerja masuk agama Islam.

Cerita berkaitan sejarah kemasukan Islam ke Samudera Pasai tersebut diteruskan dengan maklumat mengenai mimpi Merah Silu, iaitu mimpi yang ajaib, di mana Merah Silu memeluk Islam dan diajar kalimah syahadah oleh Nabi Muhammad SAW: ${ }^{18}$

28-29(15) Sebermula maka bermimpi Merah Silu dilihatnya dalam mimpinya itu ada seorang menampung dagunya dengan segala jarinya dan matanya pun ditutupnya dengan empat jarinya, demikian katanya: "Hai Merah Silu, ucap olehmu dua kalimat syahadat" Maka sahut Merah Silu: "Tiada hamba tahu mengucap akan dia". Maka ujarnya:"Bukakan Mulutmu”. Maka dibukakannya oleh Merah Silu, maka diludahnya mulut Merah Silu itu, rasanya lemak manis. Maka ujarnya akan Merah Silu: "Hai Merah Silu, engkaulah Sultan Malikul Saleh namamu, sekarang Islamlah engkau dengan mengucap dua kalimah syahadat itu, dan segala binatang yang hidup lagi halal engkau sembelih maka kau makan, dan yang tiada disembelih jangan engkau makan. Sebermula dalam empat puluh hari lagi ada sebuah kapal datang dari Makkah, barang segala katanya dan barang segala perbuatannya yang berpatutan dengan segala perkerjaan agama Islam orang yang dalam kapal itu janganlah engkau lalui, dan hendaklah engkau turut barang pengajarnya". Maka ujar Merah Silu "Siapakah tuan hamba ini?" Maka sahut suara dalam mimpi itu "Akulah Nabi Muhammad Rasulullah SAW yang di Makkah itu. Maka ditanggalkannya tangannya daripada dagunya itu. Maka sabda Rasulullah SAW akan Merah Silu itu "Tunduklah engkau ke

Tatiana, Refleksi Historiografi Alam Melayu. 
bawah". Maka tunduklah Merah Silu ke bawah serta jaga ia daripada tidurnya, maka dilihatnya yang di bawah sucilah.. Maka katanya "Asyhadu an la ilaha illa'llah wahdahu la syarika lahu, wa asyhadu anna Muhammadan 'abduhu wa rasuluhu'. Maka setelah sudah ia mengucap dua kalimah itu, maka ia membaca Qur'an tiga puluh juz khatam dengan hafalnya, ia tiada dipelajarinya lagi pada seorang jua pun. Maka ujar orang banyak dan segala hulubalang akan Merah Silu itu "Adapun raja kita ini keluar katanya itu tiada kita tahu akan barang katanya itu”.

Bukti lain boleh dilihat dalam Sejarah Melayu, iaitu perkaitan di antara Raja Palembang dengan keturunan Raja Iskandar Zulkarnain: ${ }^{19}$

16(20) Raja Palembang -Demang Lebar Daun"asalnya daripada anak cucu Raja Syulan" (dari keturunan Iskandar Zulkarnain dan juga Puteri Mathab al-Bahri-anak raja dari laut).

17(21) Pada suatu hari tiga orang muda-muda turun kepada Bukit Siguntang Mahameru dari udara. Salah satu di antaranya - Sang Seperba (Sapurba) "Maka dilihatnya tanah nagarah bukit itu menjadi emas... ketiganya memakai pakaian kerajaan dan memakai mahkota yang bertatahkan ratna mutu manikam. Ketiganya duduk di atas gajah putih... "Adapun kami ini bukan daripada bangsa jin atau peri. Bahawa kami daripada cucu anak Iskandar Zulkarnain. Nisab kami daripada Raja Nusyirwan, raja masyrik magrib, pancar kami daripada Raja Sulaiman 'alaihisalam".

18(21-22) "Mahkota inilah alamatnya tanda hamba anak cucu Raja Iskandar Zulkarnain. ...Sebab hamba jatuh ke mari ini maka padi ibuku berbuahkan emas

Tatiana, Refleksi Historiografi Alam Melayu, 32. 
dan berdaunkan perak dan berbatangkan tembaga suasa dan tanah nagarah bukit itu menjadi emas".

18(22) Maka masyhurlah pada segala negeri bahawa anak cucu Raja Iskandar Zulkarnain turun dari Bukit Siguntang Mahameru, sekarang ada di negeri Palembang.

Walaupun dalam Sejarah Melayu masih ada banyak bahan mitologi yang bukan Islam, dan berlaku sebelum Islam, tetapi maklumat berkaitan Islam menjadi lebih luas dan kandungannya lebih realistik dan terperinci. Disebutkan juga nama para ilmuwan yang wujud pada waktu itu dan juga tajuk karya Islam terkenal yang telah pun tersebar di Alam Melayu pada kurun ke-15 hingga ke-16. Dalam Hikayat Acheh terdapat unsur-unsur mitos yang sama, iaitu mitos tradisional (sebelum Islam) dan mitos baru (dipengaruhi oleh Islam). Unsur-unsur mitos tradisional yang terdapat dalam Hikayat Acheh merupakan bentuk yang lebih lengkap daripada apa yang terdapat dalam Sejarah Melayu. ${ }^{20}$ Walau bagaimanapun, dalam cerita-cerita tersebut terdapat ciri-ciri khas tamadun yang baru, iaitu tradisi Islam. Misalnya, disebutkan nama Allah SWT, terdapat rujukan kepada takdir Allah SWT, terdapat juga istilah dan nama-nama Islam, peristiwa yang penting terjadi pada hari Jumaat, anak-anak kembar daripada keturunan Iskandar Zulkarnain.

Hikayat Acheh melanjutkan konsep asal usul raja-raja Melayu, sama seperti yang dirumuskan dalam Sejarah Melayu. Raja Iskandar Zulkarnain dianggap sebagai moyang raja-raja Acheh, iaitu "14(8) Seri Sultan Perkasa Alam Johan berdaulat itu daripada ... nasab dan bangsa Raja Iskandar Zulkarnain”. Hikayat Acheh merupakan karya yang istimewa dari segi historiografi Melayu Islam. Menurut Tatiana A. Denisova, walaupun karya tersebut tergolong dalam khazanah persuratan Melayu Islam yang asli, tetapi bentuk pada garis besarnya serupa dengan riwayat hidup tokoh-tokoh penting yang muncul dalam tamadun Islam Parsi. ${ }^{21}$ Tambahan pula, menurut Teuku Iskandar Hikayat Acheh

20 Tatiana, Refleksi Historiografi Alam Melayu, 38-39.

21 Tatiana, Refleksi Historiografi Alam Melayu. 
dikarang menurut cara Akbarnama, iaitu sebuah karya untuk memuja Moghul-Agung Akbar.

Hal tersebut membuktikan bahawa Alam Melayu pada waktu itu mempunyai hubungan yang erat dengan negara Islam yang lain. Banyak karya dari tamadun Islam yang masyhur pada waktu itu telah tersebar dalam masyarakat Melayu Islam, dan kebanyakannya telah diterjemahkan ke dalam bahasa Melayu. Lebih daripada itu, pada kurun ke-16 hingga ke-17 muncul karya-karya asal Melayu, karangan para ilmuwan Melayu Islam yang dari segi bentuk dan komposisinya mengikut contoh khazanah persuratan negara Islam yang lain seperti Arab, Parsi dan India.

Dalam menyangkal pendapat Winstedt di bahagian (2), (3), (4), (5) penulis menggunakan pendekatan tekstologi, iaitu pendekatan yang mengkaji teks karya sejarah Melayu Islam kurun ke-13 hingga ke-19 dan teks terkini terbitan ahli akademik pengkhususan dalam bidang sosiologi (sains kemasyarakatan), ianya bertindak sebagai tanda kesahihan dan kebenaran maklumat ke atas apa yang dikaji. Antara teks karya sejarah Melayu Islam yang menjadi pilihan penulis adalah Sejarah Melayu, Hikayat Acheh, Hikayat Siak dan Tuhfat al-Nafis.

Penulis bermula dengan prasangka Winstedt terhadap Islam yang dilihatnya tidak sesuai dengan latar belakang masyarakat Melayu adalah tidak benar sama sekali. Punca utama yang menyebabkan masyarakat Melayu memilih Islam sebagai asas jati diri kemelayuan telah dilihat oleh kebanyakan sarjana moden antara lainnya adalah kerana kesucian dan kesempurnaan ajaran Islam itu sendiri yang boleh dijelaskan dengan beberapa penerangan:

1) Ajaran Islam amat bersesuaian dengan psikologi dan mentaliti masyarakat Melayu yang mengamalkan cara hidup yang lemah lembut ${ }^{22}$ dan bersifat 'alami (menghormati keharmonian alam).

2) Sifat ajaran Islam yang mudah difahami, rasional dan

22 Wan Abdul Halim Othman, "Hubungan Kekeluargaan Dalam Masyarakat Melayu", dalam Psikologi Melayu (Kuala Lumpur: Dewan Bahasa dan Pustaka, 1993), 61-101. 
sesuai dengan fitrah manusia berbanding dengan agama lain. $^{23}$

3) Cakupan agama Islam tidak bersifat perkauman yang terhad kepada sesuatu bangsa semata-mata, ${ }^{24}$ tetapi merangkumi semua ras manusia sedunia yang dibina di atas asas persaudaraan. Asas persaudaraan ini juga tidak menerima segala bentuk pembahagian kasta manusia yang mengakui semua manusia adalah sama martabatnya di sisi Allah SWT. Dalam Tuhfat al-Nafis, ada menyebutkan kriteria mengenaisifat "keterbukaanterhadapkebudayaan lain" termasuk kebudayaan orang Barat, iaitu "Raja suka bersahabat dengan orang baik-baik, termasuk orang putih, suka kepada muzik Eropah dan "menyuruh budakbudak empat lima orang belajar muzik cara Holanda ke Melaka, iaitu belajar tambur dan seruling dan trompet dan biola dan lainnya daripada segala perkakas bermain muzik". Maklumat ini menafikan prasangka bahawa Islam sejak awal lagi adalah terlalu agresif dan bersifat bermusuhan terhadap penganut agama lain, terutama terhadap orang Eropah. ${ }^{25}$

Pemilihan Islam sebagai asas jati diri ini ternyata telah menguntungkan masyarakat Melayu kerana seperti mana yang berlaku kepada masyarakat Arab, Islam juga telah mengangkat martabat tamadun Melayu ke peringkat antarabangsa. ${ }^{26}$ Proses ini antara lainnya telah menimbulkan semangat perpaduan dalam

23 S.M. Naquib al-Attas, Preliminary Statement on A General Theory of The Islamization of The Malay-Indonesian Archipelago (Kuala Lumpur: Dewan Bahasa dan Pustaka, 1969), 4-7.

24 Seperti mana dipegang oleh agama Yahudi bahawa bangsa tersebut adalah bangsa pilihan Tuhan. Lihat Ghazali Darusalam, Dakwah Islam dan Idealogi Barat (Kuala Lumpur: Utusan Publications \& Distributors, 1998), 30-39.

25 Untuk mengetahui lebih lanjut apa yang disebut dalam Tuhfat alNafis berkaitan sifat orang Melayu, sila rujuk Tatiana A. Denisova, Refleksi Historiografi Alam Melayu, 146-150.

26 Hashim Musa, Merekonstruksi Tamadun Melayu Islam: Ke Arah Pembinaan Sebuah Tamadun Dunia Alaf Ketiga (Kuala Lumpur: Akademi Pengajian Melayu, Universiti Malaya, 2001), 3-4. 
kalangan umat Islam di Tanah Melayu bahawa kedudukan mereka di dalam kerangka tauhid, ummah dan ukhwah bukan terhad kepada lingkungan kawasan dan sejarah Alam Melayu sematamata, bahkan turut membabitkan semua umat Islam seluruh dunia dari setiap zaman dengan warisan tamadun yang tinggi.

Hasil penelitian terhadap buku Refleksi Historiografi Alam Melayu karya Tatiana A. Denisova, dalam historiografi Melayu Islam sudah wujud suatu konsep keadilan yang umum sifatnya. Bermula dari raja yang adil hingga ke rakyatnya, mengandungi sifat-sifat kemanusiaan seperti berbudi dan beradab, bahasa yang ikhlas, keberanian, kesabaran, pemurah, kebijaksanaan, menyebar dan mengukuhkan Islam, memerintah dengan adil, patuh kepada undang-undang, menuntut ilmu, berakhlak, mahir dengan ilmu pelayaran, perdagangan dan sebagainya. ${ }^{27}$

Dengan konsep jati diri ini, masyarakat Melayu merasa bangga menganut agama Islam yang menjadikan mereka sebahagian daripada serangkaian ummah Islam, seperti mana halnya golongan Arab yang dipandang mulia oleh masyarakat Melayu. ${ }^{28}$ Faktor inilah juga yang menyebabkan di dalam sejarah Alam Melayu kerap berlaku penentangan masyarakat Melayu terhadap kuasa penjajah Barat yang dianggap sebagai kuasa kafir dan hal ini telah diakui sendiri oleh mubaligh Kristian yang mengatakan masyarakat Melayu sebagai golongan yang kuat berpegang kepada agama Islam..$^{29}$ Apa yang jelasnya, sifat kemelayuan yang begitu sebati dengan Islam ini telah mengakibatkan sebarang bentuk serangan yang dibuat terhadap Islam akan dianggap seperti serangan yang dibuat terhadap asas kebudayaan Melayu. ${ }^{30}$

Seterusnya, di atas dasar ukhwah dan ummah Islam ini semua masyarakat Melayu yang mendiami rantau Alam Melayu telah berjaya disatukan dan menjalin hubungan yang erat sesama

Tatiana, Refleksi Historiografi Alam Melayu, 204.

28 W.R. Roff, The Origins of Malay Nationalism, terj. Ahmad Boestamam Nasionalisme Melayu, cet. 3, (Kuala Lumpur: Penerbit Universiti Malaya, 2005), 1-136.

29 Charles Tisdall, "Ideas of Mohammedan Malaya", dalam The Missionary Review of the World, v. xxxiv, (1916): 348-349.

30 Isabella Bird, The Golden Chersonese and the Way Thither (Kuala Lumpur: Oxford University Press, 1967), 20. 
penganut Islam. Dalam soal ini, kita boleh melihat dua bentuk jalinan yang telah ditimbulkan oleh Islam, iaitu:

Pertama, hubungan intelektual yang mementingkan ilmu pengetahuan berasaskan pemupukan budaya ilmu yang sejati. ${ }^{31}$ Hubungan intelektual ini telah dijalinkan terutama yang bersangkutan dengan keperluan kepada tenaga-tenaga ulama untuk membantu usaha menyuburkan Islam di Alam Melayu. Hal ini terbukti apabila setiap kawasan di Alam Melayu mengamalkan sikap keterbukaan yang menerima kehadiran seseorang ulama luar dan kerap dilantik sebagai pakar rujuk untuk sesuatu institusi Islam, ${ }^{32}$ begitu juga setiap kawasan saling bergantungan antara satu sama lain di dalam menentukan sesuatu pegangan keagamaan Islam. Sebagai contohnya, walaupun Syeikh Nuruddin ar-Raniri berasal dari India, tetapi beliau telah dilantik sebagai pakar rujuk utama untuk kerajaan Acheh. ${ }^{33}$ Begitu juga banyak persoalan agama yang rumit, yang berlaku di kerajaan Melaka telah dirujuk secara rasmi kepada jemaah ulama di Acheh. Oleh sebab itu, dalam kerangka ini tidak hairanlah kalau ulama Patani dan kawasan lain telah diterima secara positif oleh masyarakat Islam di Tanah Melayu.

Kedua, hubungan politik dan diplomatik Islam antara kerajaan Alam Melayu dengan kerajaan Islam dunia. Hubungan politik ini telah dilihat mampu memperkukuhkan keadaan politik dalaman sesebuah kerajaan Melayu Islam. ${ }^{34}$ Mana-mana musuh asing yang beragama selain Islam seperti Kristian dan Buddha yang bertindak menceroboh sesebuah wilayah umat Islam akan dianggap sebagai musuh dan kerap kali bantuan ketenteraan telah diberikan oleh kerajaan Islam Alam Melayu yang lain. ${ }^{35}$

31 Lihat Wan Mohd Nor Wan Daud, Penjelasan Budaya Ilmu (Kuala Lumpur: Dewan Bahasa dan Pustaka, 1991), 108-109.

32 B.J.O. Schrieke, "Indonesian Sosiological Studies", dalam The Hague, vol. 2, (1957): 261.

33 Lihat Abdul Rahman Abdullah, Pemikiran Umat Islam di Nusantara (Kuala Lumpur: Dewan Bahasa dan Pustaka, 1990), 127-130.

34 Lihat Nasir Abdullah, "Turki dan Alam Melayu: Tinjauan Terhadap Sejarah Hubungan Keduanya", dalam Jebat 15, (1987): 129-142.

35 Ibrahim Abu Bakar, Islamic Modernism in Malaya (Kuala Lumpur: University of Malaya Press, 1994), 2-6. 
Selepas Islam tersebar ke Alam Melayu, jumlah kapal asing seperti Arab, Parsi, India dan China yang berkunjung di laut Nusantara semakin lama semakin banyak. Pengembara Mesir yang bernama Claudius Ptolemaus (100-170) telah menamakan Semenanjung Melayu sebagai Golden Khersonese (Semenanjung Emas) dan memperkenalkan Tanah Melayu kepada dunia Barat. ${ }^{36}$ Bukti hubungan diplomatik tersebut, boleh dilihat dari segi intelektual dan perdagangan dalam teks Sejarah Melayu, ${ }^{37}$ iaitu:

50(59) Esok hari, apabila waktu Asar datang sebuah kapal dari Jeddah, maka turun orang dari kapal itu di pantai Melaka ini. (Pelayaran)

151(191) Maka turun sebuah kapal dari atas angin ke Melaka. Dalam kapal itu ada seorang pandita Maulana Sadar Jahan namanya, terlalu alim. (Penyebaran Islam)

59(69).... Maka datang sebuah kapal dari atas angin. Setelah kapal itu berlabuh, maka segala nelayan sekalian datang berjual ikan pada orang dalam kapal itu... Adapun dalam kapal itu ada seorang maulana namanya Maulana Jalaluddin. (perniagaan)

Maka Tun Perpatih Putih... dititahkan Sultan Mansur Syah utus ke Benua China... setelah berapa lamanya di jalan maka sampailah ke Benua China. Maka oleh Raja China disuruhnya arak surat dari Melaka itu dihentikan di rumah perdana menteri yang bernama Li Po. (Hubungan Politik)

139(175) Maka Sultan Mahmud Syah pun hendak menyuruh ke Benua Keling membeli kain empat puluh bagai, pada sebagai empat helai kain, pada sehelai kain empat puluh balai bunganya. Maka

\footnotetext{
36 Ahmad Jelani Halimi, Perdagangan dan Perkapalan Melayu di Selat Melaka Abad Ke-15 hingga Ke-18 (Kuala Lumpur: Dewan Bahasa dan Pustaka, 2006), 1-7.

37 Lihat Tatiana, Refleksi Historiografi Alam Melayu, 294-315.
} 
Hang Nadim dititahkan baginda ke Benua Keling. (Perniagaan)

Manakala bukti dari teks Hikayat Acheh:

165(68) Jikalau ada saudaraku yang di Acheh menaruh kuda tizi yang lain atau kuda bangkas dari Makkah atau dari Istanbul...

233(94) Beberapa dagang-dagang daripada Arab dan Ajam dan Rumi dan Mughul dan segala Hindi yang melihat sungai itu. (Perdagangan)

Selain itu, teks dari Hikayat Siak:

605(245) Tengku Akil berjaga dengan segala kawankawan dan sordadu, segenap pintu. Dan pintu kota ditutup. Dan yang di dalam Kota Lama, Cina empat ratus, dan orang Maskat sepuluh orang, menolong Sultan Muda. (Politik)

Teks dari Tuhfat al-Nafis:

292(316) Maka ramailah negeri Lingga masuklah perahu dagang dari Jawa dan wangkang-wangkang dari negeri Cina dan dari Siam dan lainnya. (Perdagangan)

Peranan politik kesultanan Islam tempatan di Alam Melayu amat besar sekali, bukan setakat dari tindakan menjemput ulama Islam asing selaku penasihat untuk usaha pemerintahan negara, bahkan juga turut menjalin hubungan erat dengan pemerintah kota Makkah. ${ }^{38}$ Hubungan ini telah mendedahkan Alam Melayu kepada masyarakat Islam di Timur Tengah yang kemudiannya secara langsung telah memesatkan lagi jalinan intelektual antara kedua-dua kawasan ini. Hasil hubungan dua hala tersebut, boleh menyaksikan bagaimana ulama Melayu telah bertindak sebagai intelektual ummah dalam beberapa perkara:

38 Abd Jalil Borham, "Sumbangan Ulama dalam Perkembangan Islam di Alam Melayu”, dalam Jurnal Syariah 4, no. 2 (1996): 276-277. 
1) Perancang kepada usaha yang berkesan untuk memperkenalkan agama Islam ke dalam masyarakat Melayu. ${ }^{39}$

2) Pembasmi nilai-nilai feudalisme dan adat pra-Islam yang berakar umbi di dalam kehidupan masyarakat melalui institusi pendidikan Islam. ${ }^{40}$

3) Penanam benih budaya ilmu ke dalam masyarakat Melayu yang mampu melahirkan sejumlah manusia Melayu yang celik agama serta mampu bertindak mengikut perkiraan ilmunya, menyebarkannya ke dalam masyarakat dan berfungsi sebagai pemimpin masyarakat. ${ }^{41}$ Ianya juga telah melahirkan masyarakat Melayu yang berakhlak tinggi dan mampu berdikari tanpa bergantung kepada orang lain. ${ }^{42}$

4) Pemangkin kepada usaha penerapan nilai-nilai Islam ke dalam kebudayaan masyarakat Melayu sehingga agama tersebut menjadi jati diri yang utama kepada kelangsungan diri mereka. ${ }^{43}$

5) Penasihat kepada pemerintah Melayu di dalam usaha menerapkan nilai-nilai Islam ke dalam sistem undang-

39 Abdul Halim el-Muhammady, "Dakwah dan Kesannya dalam Kehidupan Masyarakat Melayu Tradisional", dalam Dinamika Dakwah: Suatu Perspektif Dari Zaman Awal Islam Hingga Kini, (Kuala Lumpur: ABIM, 1992), 173-184.

40 Rahimin Affandi Abdul Rahim, "Fiqh Malaysia: Suatu Tinjauan Sejarah", dalam Fiqh Malaysia: Ke Arah Pembinaan Fiqh Tempatan Yang Terkini (Kuala Lumpur: APIUM, 2000), 22-25.

41 Lihat Shafie Abu Bakar, "Keilmuan Islam dan Tradisi Pengajian Pondok", dalam Budi Kencana (Kuala Lumpur: Dewan Bahasa dan Pustaka, 1994), 101-103.

42 Abdullah Ishak, Pendidikan Islam dan Pengaruhnya (Kuala Lumpur: Dewan Bahasa dan Pustaka, 1982), 202-204.

43 Winstedt, "A History of Malaya", dalam JMBRAS, vol. x, (1932): 69-90. 
undang masyarakat Melayu, ${ }^{44}$ sehingga melahirkan sejumlah besar "Malay Digest” Melayu Islam.

6) Perancang dan pencipta sistem komunikasi dakwah iaitu tulisan jawi yang berkesan di dalam masyarakat dan kemudiannya telah menjadi bahasa perantaraan (lingua franca) untuk perkembangan ilmiah Islam dan hubungan antarabangsa. ${ }^{45}$

Seterusnya, apa yang dikatakan oleh Winstedt bahawa Islam tidak boleh dianggap sebagai way of life (al-Din), tetapi hanya sebagai hasil sejarah silam yang tidak releven lagi untuk zaman sekarang adalah tidak benar sama sekali. Menurut Winstedt di dalam karyanya The Malays: A Cultural History,

"Education has already rid the Malay of ghostly terrors, and taking the professions, trade and agriculture to be its province has provided his race with fresh equipment for the battle of life. Having to learn to read the Kuran in Arabic, a language he does not understand, is a strain on the Malay child that is not undergone by the other races of Malaya. But the educational system has produced Malays who have taken honours at Cambridge and have been called to the bar and qualified as doctors and engineers. Continued social progress will depend on the extension of all types of education suited to local needs, and that extension will depend on satisfactory political and economic conditions".

44 Ismail Mat, "Pengajian Syariah: Hubungannya Dengan Adat Arab dan Keadaan di Malaysia", dalam Dinamisme Pengajian Syariah (Kuala Lumpur: Berita Publishing, 1997), 89-90.

45 Lihat Mohammad Redzuan Othman, "The Middle Eastern Influence on the Development of Religious and Political Thought in Malay Society 1880-1940" (Thesis Ph.D untuk University of Edinburgh, 1994), 53-55 \& Omar Awang, "The Major Arabic Sources Which Determined the Structure of Islamic Thought in the Malay Archipelago Before the Nineteenth Century A.D. in the Field of Law", dalam ISLAMIKA, (1981): 80-85. 
Pernyataan tersebut jelas menunjukkan bagaimana Winstedt memperkecilkan sumbangan Islam dalam kehidupan masyarakat Melayu di Tanah Melayu.

Selain itu, Winstedt turut menafikan kepandaian masyarakat Melayu berpunca dari penganutan mereka terhadap agama Islam, iaitu "The Malay is still a child of nature in a sophisticated world that awaits his exploration. If any Malay should develop an original literary bent, it is more likely that the impulse will come from densely populated Java or even from Sumatra rather than from the two and a half million Malays of the peninsula, though it is not always the probable that happens".

Agama Islam seperti yang diperjelaskan oleh sarjana teologi Islam adalah bersifat tetap, fleksibel mengikut kesesuaian untuk sepanjang zaman dan tidak boleh berubah sehingga kiamat. Ringkasnya, walau apa pun bentuk dialog antara agama yang dilakukan, pendekatan ala sekularisme yang menolak peranan ketuhanan dalam kehidupan manusia dan bergantung sepenuhnya kepada peranan akal dan nafsu manusia di dalam menentukan segala aspek terpenting di dalam kehidupan perlu dijauhkan sama sekali. Lebih buruk lagi, mengikut pendekatan kajian sekularisme sebarang elemen yang berkaitan dengan fenomena ketuhanan dan metafizik akan dianggap sebagai karut dan tidak bersifat empirikal. Bahkan mereka menganggap penderitaan manusia adalah berpunca dari kelemahan sifat manusia itu sendiri yang tertipu dengan berpegang kepada kepercayaan keagamaan.

\section{KESIMPULAN}

Kesimpulannya, Winstedt dalam mengkaji pembawaan agama, budaya dan pemikiran orang Melayu adalah dengan menggunakan sudut pandangan yang skeptikal, malah beliau dengan angkuhnya mengatakan bangsa ini mesti ditamadunkan dengan segera supaya tidak lagi menjadi bangsa yang lemah dan ketinggalan dari arus pemodenan.

Salah satu sebab sikap sedemikian adalah konsep EuroCentric dan sikap pengabaian terhadap peranan Islam di Alam Melayu. Biasanya para orientalis menganggap Islam sebagai faktor negatif dalam proses perkembangan Alam Melayu. 
Mereka tidak mahu memerhatikan bahawa Islam memajukan perkembangan masyarakat dan bangsa Melayu, mereka juga tidak mahu memerhatikan bahawa Islam berpengaruh dalam usaha mengembangkan kebudayaan dan pemikiran umum, termasuk juga ilmu, falsafah dan bahasa Melayu. Dalam soal ini Winstedt dengan fanatiknya telah menegaskan pihak British merupakan penyelamat masyarakat Melayu, "Though his very name has been forgotten at Kuala Kangsar, Captain James Low was the saviour of Perak.. and along with the name of Low, Perak ought to enscribe in the letters of gold the name Robert Fullerton, Governor of Prince of Wales Island, Singapore and Malacca".

\section{BIBLIOGRAFI}

Abd Jalil Borham. "Sumbangan Ulama dalam Perkembangan Islam di Alam Melayu". Jurnal Syariah 4, no. 2 (1996).

Abdul Halim el-Muhammady. "Dakwah dan Kesannya dalam Kehidupan Masyarakat Melayu Tradisional." Dalam Dinamika Dakwah: Suatu Perspektif Dari Zaman Awal Islam Hingga Kini. Kuala Lumpur: ABIM, 1992.

Abdul Malik Karim Amrullah. "Masuk dan Berkembangnya Agama Islam di Daerah pesisir Sumatera Utara". Dalam Sejarah Masuknya Islam ke Indonesia: Risalah Seminar. Medan, 1963.

Abdul Rahman Abdullah. Pemikiran Umat Islam di Nusantara. Kuala Lumpur: Dewan Bahasa dan Pustaka, 1990.

Abdul Rahman Abdullah. Wacana Falsafah Sejarah: Perspektif Barat dan Timur. Kuala Lumpur: Dewan Bahasa dan Pustaka, 2000.

Abdullah Ishak. Pendidikan Islam dan Pengaruhnya. Kuala Lumpur: Dewan Bahasa dan Pustaka, 1982.

Ahmad Jelani Halimi. Perdagangan dan Perkapalan Melayu di Selat Melaka Abad Ke-15 hingga Ke-18. Kuala Lumpur: Dewan Bahasa dan Pustaka, 2006. 
Anwar Din. Asas Kebudayaan dan Kesenian Melayu. Bangi: Penerbit Universiti Kebangsaan Malaysia, 2007.

Arnold, T. Preaching of Islam. London, 1913.

Auni Abdullah. Tradisi Pemerintahan Islam \& Kolonialisme Dalam Sejarah Alam Melayu. Kuala Lumpur: Darul Fikir Sdn. Bhd., 2005.

Bird, Isabella. The Golden Chersonese and the Way Thither. Kuala Lumpur: Oxford University Press, 1967.

Denisova, A. Tatiana. "Islam di Dalam Alam Melayu Abad ke-VII sehingga ke-XIII.” Dalam Sejarah Perkembangan Tamadun Islami 1, 2001.

Denisova, A. Tatiana. Refleksi Historiografi Alam Melayu. Kuala Lumpur: Penerbit Universiti Malaya, 2011.

Ghazali Darusalam. Dakwah Islam dan Idealogi Barat. Kuala Lumpur: Utusan Publications \& Distributors, 1998.

H.M. Zainuddin. Tarich Atjeh dan Nusantara. Medan: Pustaka Iskandar Muda, 1961.

Hashim Musa. "Islam: An Overview in History and Contemporary World." Jurnal AFKAR 2 (2001).

Hashim Musa. Merekonstruksi Tamadun Melayu Islam: Ke Arah Pembinaan Sebuah Tamadun Dunia Alaf Ketiga. Kuala Lumpur: Akademi Pengajian Melayu, Universiti Malaya, 2001.

Ibn Kathīr. Tafsìr al-Qur'ān al-'Az̄imm. Vol. 1. Bayrūt: Dār alMa'rifah, 1982.

Ibn Khurdadhbeh. Kitāb al-Masālik wa al-Mamālik. Ed. M.J. De Goeje. Leiden, 1889.

Ibrahim Abu Bakar. Islamic Modernism in Malaya. Kuala Lumpur: University of Malaya Press, 1994.

Idris Zakaria. "Intelek Eropah dan Penentangan Terhadap Agama". Dalam Al-Maw'izah 7 (1999). 
Ismail Mat. "Pengajian Syariah: Hubungannya Dengan Adat Arab dan Keadaan di Malaysia." Dalam Dinamisme Pengajian Syariah. Kuala Lumpur: Berita Publishing, 1997.

Landon, K.P. Southeast Asia: Crossroad of Religions. Chicago: University of Chicago, 1949.

Mohammad Redzuan Othman. "The Middle Eastern Influence on the Development of Religious and Political Thought in Malay Society 1880-1940”. Thesis Ph.D, University of Edinburgh, 1994.

Mohd Kamal Hassan. Toward Actualizing Islamic Ethical and Educational Principles in Malaysia. Kuala Lumpur: ABIM, 1996.

Muhammad Zainiy Uthman. "Islam, Sains dan Pemikiran Objektif: Suatu Perbandingan Ringkas". Jurnal YADIM 2 (2001).

Nasir Abdullah. "Turki dan Alam Melayu: Tinjauan Terhadap Sejarah Hubungan Keduanya”. Jebat 15 (1987).

Omar Awang. "The Major Arabic Sources Which Determined the Structure of Islamic Thought in the Malay Archipelago Before the Nineteenth Century A.D. in the Field of Law". ISLAMIKA, 1981.

Rahimin Affandi Abdul Rahim. "Fiqh Malaysia: Suatu Tinjauan Sejarah". Dalam Fiqh Malaysia: Ke Arah Pembinaan Fiqh Tempatan Yang Terkini. Kuala Lumpur: APIUM, 2000.

Ramli Awang. Tasawwur Rabbani Menurut Al-Quran dan Sunnah. Kuala Lumpur: Al-Hidayah Publications, 2001.

Roff, W.R. The Origins of Malay Nationalism. Terj. Ahmad Boestamam. Nasionalisme Melayu. Cet. 3. Kuala Lumpur: Penerbit Universiti Malaya, 2005.

S. Muhammad Hussayn Nainar. Islam di India dan Hubunganhubungannya dengan Indonesia. Medan: Information Service of India, 1956. 
S.M. Naquib al-Attas. Preliminary Statement on A General Theory of The Islamization of the Malay-Indonesian Archipelago. Kuala Lumpur: Dewan Bahasa dan Pustaka, 1969.

Schrieke, B.J.O. "Indonesian Sosiological Studies". Dalam The Hague, v. 2, (1957).

Shafie Abu Bakar. "Keilmuan Islam dan Tradisi Pengajian Pondok." Dalam Budi Kencana. Kuala Lumpur: Dewan Bahasa dan Pustaka, 1994.

Takakusu, J. I Tsing: A Record of the Buddhist Religion as Practiced in India and the Malay Archipelago (A.D. 671695). Delhi: Oxford University Press, 1966.

Tisdall, Charles. "Ideas of Mohammedan Malaya." Dalam The Missionary Review of the World, v. xxxiv, 1916.

Turner, Bryan S. "Gustave E. Von Grunebaum and the Mimesis of Islam." Dalam Orientalism, Islam and Islamist. Vermont: Amana Books, 1984.

W.M. Watt. "Economic and Social Aspects of the Origin of Islam", dalam The Islamic Quarterly 1, pt. 1, 1954.

Wan Abdul Halim Othman. "Hubungan Kekeluargaan Dalam Masyarakat Melayu". Dalam Psikologi Melayu, Kuala Lumpur: Dewan Bahasa dan Pustaka, 1993.

Wan Mohd Nor Wan Daud. Penjelasan Budaya Ilmu. Kuala Lumpur: Dewan Bahasa dan Pustaka, 1997.

Winstedt, R.O. "A History of Malaya." Dalam JMBRAS. Vol. x, 1932.

Winstedt, R.O. "The Advent of Muhammadanism in the Malay Peninsula and Archipelago". Dalam JSBRAS, 1917.

Winstedt, R.O. "The Early Muhammadan Missionaries." Dalam JSBRAS, 1920.

Winstedt, R.O. A History of Classical Malay Literature. Kuala Lumpur: Oxford University Press, 1969. 
Winstedt, R.O. A History of Malaya. Kuala Lumpur: Marican \& Sons, 1988.

Winstedt, R.O. Shaman, Saiva and Sufi: A Study of the Evolution of Malay Magic. London: Constable, 1925.

Winstedt, R.O. The Malay: A Cultural History. London: Routledge \& Kegan Paul Ltd, 1961.

Zainal Kling. "Antropologi Tafsiran: Sumbangan Kebudayaan Melayu Kepada Teori." Dalam Syarahan Perdana Untuk Pengukuhan Profesor. Kuala Lumpur, 1994. 